\title{
Hospice Care for End of Life Client in the Culture of Mountain and Beach of Papuan
}

\author{
Agussalim $^{1 *}$ and Masdiana ${ }^{2}$ \\ 10ffice Ministry of Health Indonesian Republic Health Polytechnic of Jayapura, Papua Province, Indonesia \\ Nursing School of Diploma, Health Polytechnic of Makassar, South Sulawesi Province, Indonesia
}

*Corresponding author: Agussalim, Office Ministry of Health Indonesian Republic Health Polytechnic of Jayapura, Papua Province, Indonesia

To Cite This Article: Agussalim, Hospice Care for End of Life Client in the Culture of Mountain and Beach of Papuan. 2020 - 7(5). AJBSR. MS.ID.001191. DOI: 10.34297/AJBSR.2020.07.001191.

Received: 眥 February 19, 2020; Published: 制 February 27, 2020

\begin{abstract}
Minireview
Background: In the culture of Indonesia as the country's East, when a patient in a terminal condition in the verdict and discussed with her family, they tend to bring patients back home and out of the hospital by force to their care at home.

The method: This type of research is descriptive qualitative approach phenomenology study i.e. Research generates data in the form of descriptive words written or oral from informants and behavior that can be observed.

The Result: In depth interview with a participant found that for the entire territory of Papua has not found the preparation of palliative patients handling in particular is especially done in palliative care clinic and also in the community.

Discussion: Handling of palliative patients should be conducted in a comprehensive manner which is not only in the hospital but also in community clinics.
\end{abstract}

Keywords: Hospice Care, Culture, Papuan, Remote area, Community Health Center.

\section{Introduction}

Development and advancement of the health of the world by leaps and bounds lately have made the world of medicine and nursing a lot of dealing with the problem of quaint. As globalization increasingly demanding turnaround improved quality individually, then the improved quality is the thing that absolutely needs to be done in order not to be left behind with the rotation of the times. Similarly, in the field of nursing services, improving the services must be by the values of professionalism. Professional nursing services should be grounded by the intellectual values, moral commitment towards self, and responsibility towards society, autonomy, and control. Therefore, health workers expected to contribute optimally in accordance with knowledge, technology and aesthetics of patient care [1].

The increasing number of patients with a disease that is not yet curable at both adults and children such as cancer, lung disease, degenerative, chronic airway diseases, cystic fibrosis, stroke, Parkin son's, heart failure, disease and genetics infectious diseases such as HIV/AIDS who need palliative care, in addition to promotion, preventive, curative, and rehabilitative. Currently the Ministry of health in Indonesia have not yet touched on the needs of patients with a disease that is difficult to be cured, especially on next stadium where is priority of service not only in healing but also in order to achieve quality care life is best for the patient and his family. At an advanced stage patient with chronic diseases are not only experience a variety of physical problems such as pain, shortness of breath, weight loss, interruption of activities but also psychosocial and spiritual disorder that affects quality of life patients and their families. Then the needs of patients in advanced stages of a disease not only physical symptoms/treatment compliance, but also the importance of the support to the need of psychological, social and spiritual conducted by an interdisciplinary approach is known as palliative care. 
The needs of patients in advanced stages of a disease not only physical symptoms/treatment compliance, but also the importance of the support to the need of psychological, social and spiritual conducted by an interdisciplinary approach is known as palliative care. Palliative care is a form of medical care and comfort patients who control the intensity of the disease or slow its growth, whether or not there is hope to recover.

Approach the palliative care that can effectively improve the quality of life of patients [2]. The community considers the palliative care only for patients in the terminal condition that will soon be dead. But new concepts of palliative care emphasize the importance of early treatment palliative more integration so that problems of physical, psychosocial, and spiritual can be overcome by good. Palliative care is holistic and integration which health services by involving various professions on the basis of fundamentals that every patient deserves the best care until his death. Palliative care is an approach to developing the quality of life of the patient and the family of the problems associated with life-threatening illnesses, on a variety of disorders is chronic or terminal illness. Palliative care focuses on aspects of the multifactor such us psychological, social, spiritual, physical, and interpersonal and cures components.

According to Tejawinata (2006), one important aspect in palliative care is love saying, caring, sincere, and gratitude. So, the importance of these aspects are to exceed the importance of handling an absolute pain to do in palliative care. He also stated, on a cancer client is not possible palliative nurse again; incurable illness is basically an attempt to prepare the beginning of a new life (afterlife). It makes no difference with the content of treatment done a prospective mother, who from the very beginning of her routine check to ensure his health and a growing swell of prospective baby, in order to pass through the birth process with healthy and happy, next in his new life as a human being can grow into a human healthy and quality.

Another way to see palliative care is the concept of "a good death" free from avoidable pain and suffering for the patient and the patient's family. At first glance, this definition seems to have little to do with acute care delivered in settings such as emergency, even reported at least $35 \%$ of the patients want to die at home. As a result, many terminally ill are patients which present to the Emergency Department. They can do that when death is near, for the treatment of acute illness superimposed on the existing illnesses on them, or to control the symptoms, especially pain.

Issues that are crucial in the field of bioethics and bio law are concerned the "life and death". For the life of a need to eat and drink, sometimes in a State of pain, a patient cannot eat themselves, so should be given nutrition and hydration by a nose (Naso Gastric Tube). According to calculations in General a could survive for 40 (forty) days without eating. A fatty client instead can survive more because fat cells slowly land will be ruined and provides durability.
Without drinking (liquid) someone would die quicker in time 3 - 10 days depending on your health and energy.

With the progress of science and technology in the field of nursing and medic, the life of a patient can be extended by giving fluids through NGT and giving help breathing through ventilators. ICU doctors now often on expose's dilemma whether the granting of the aid have to go through this life is given or not and who have given or stopped. The doctors and nurses had already been detained for helping a patient soul, but now have to decide whether they could "answer to the patient died". Otherwise it is no longer possible to help him. If it remains conducting, the sufferer will it be extended and sometimes the patient is no longer her suffering. Indeed, the issue are casuistic, so a definite guideline and is not possible given the raw. Responsibility towards the doctor conscience and beliefs and religions are adhered to. Also depending to the laws of the applicable is stated [3].

In the culture of Western treatment is each patient in the liability by insurance. Each patient's care needs including bio, psycho, and the spiritual primary on the patient's terminal illness characterized by care and medical personnel in a hospital or hospice. In the culture of Indonesia as the country's East, when a patient in a terminal condition in the verdict and discussed with her family, they tend to bring patients back home and out of the hospital by force to their care at home. On the other hand, they still desperately need care by holistic palliative health workers from hospitals or clinics. The concept of palliative care family and community are from clinics and referral system of hospitals to clinics that do not exist well in Indonesia [4-8].

\section{Statement of the Study}

Based on the background issues written above we're interested in doing a research in palliative referral system-level hospitals to Clinics with the title "Hospice Care on the client End of Life/Palliative in the involvement of the House pain and clinics as consul and satellites in the inland and coastal community affordability “.

\section{Method of Research}

This type of research is descriptive qualitative approach to phenomenology the study i.e. research that generates descriptive data in the form of the written word or spoken of people and behavior that can be observed. While according to Husserl (Creswell, 1998) phenomenological researchers trying to find about things that need to be (essential), the structure of invariant (the essence) or the meaning of the fundamental experience and emphasis on intensity of awareness where experience is composed things looked from the outside and the things that are in the consciousness of each based on memory, image and meaning. In this research we are trying to find about palliative care activities have been done or still to be developed by the hospitals and clinics as well as what is perceived and required by the client and his family when the patient has returned to his home $[9,10]$. 
The method of data collection used in this study is an in-depth interview with (Deep Interview) against the informant (Moleong, 2000) who assisted with guidelines in the form of standard interview questions open (open question). The number of respondents who obtained in the field after selection based on the criteria of the subject who has been assigned as many as 24 informants. Interviews are done in Clinics, hospitals, and hospital care. Interview done 1-2 times with the length of time varies according to the circumstances and conditions but the average interview for 5 minutes, as well as on the basis of the agreed contract. Prior to interview informants proffered inform consent to be read and signed by him.

Each person selected to do the interview, by asking the same questions of each person who will be in the interview. The method of interview is structured. This interview is intended to obtain information (view, beliefs, experiences and knowledge) orally from person/informant about a thing (Notoadmodjo, 2002). Other activities that can be done to get the data are the observation and study of documents from Clinics and hospitals. Data collection begins with the determination in accordance with the criteria of informant sample. Before starting the interview, researchers create relationships of mutual trust with the informant. Researchers introduce yourself in advance with explains the meaning and purpose of the research. After the informants understand the purpose of the research will be conducted and my father learned the informant doesn't mind the questions to be asked as well as understand their rights as informants. Researchers asked the informant to sign a letter of willingness to participate. Then researchers make contracts for the first meeting concerning the time and place of execution of the interview. The next step is done interviews for dig up information about a research problem.

Interview done once during the 5-10 meeting minutes each time. Interview time adapted to the conditions and situation of the informant at the time of the interview. At the end of each interview the informant about the comment asked interview process, what they feel about the interview and what do researchers to repair interview process. During the interview process, in addition to using tape recorders researchers also make note that aims to write the circumstances or situations during the interview and all the non-verbal response is indicated by the informant. It is intended to assist researchers in order to plan the next new questions as well as help to get the important points in the interview, so in order to make it easier analysis. After the interview was completed, the researcher and the informants made a contract/promise to decide the time and place of the next meeting of the implementation. The validity of research results is the credibility of the results of scientific power reset and used to answer the questions discussed strategy with arranged to increase validity and rehabilitees, for it used four areas specifically:
a. Credibility (internal validity),
b. Transferability (external validity),

c. Dependability (dependence) and

d. The Conformability (neutral) (Lincolnm and Guba in Brockop d et al. 2000).

Operationally credibility can be achieved with the dwarf member check IE at the end of each interview subject, researchers repeated the back outline the results of interviews oral or written report to the respondent. This is intended so that researchers can improve the results of the interview when there are errors. Transferability (external validity) of the criteria can be seen depending on reader research results i.e. up to where research results are used in a particular context. If readers feel there is harmony with the situation then this researcher has transferability. Dependability (degree of dependence) researchers carefully follow all session related to the interpretation of the data. All records kept for further reference and reflection. Confirm is the final stage of the process of auditing the results of researchers. Confirm can be reached when credibility, transferability, dependability and met (Brockop D2000 et al.).

\section{Discussion}

Researchers have identified 5 themes that are the result of this research. The themes identified by the purpose of the research. An overview of the results of research activities that have been carried out successfully identifies 5 themes that are important in analyzing and identified problems that exist in the province of Papua are associated with palliative care patients $[11,12]$.

\section{a. Hospital preparedness in handling the patient's end} of life care.

In this study found facts empirically through in-depth interviews with the leadership in the three county hospitals in the province of Papua has about their readiness in conducting palliative care i.e., unavailability of the Centre or palliative service at the hospital which became the sample in this research. In the concept of holistic treatments, patients with its head right to get care throughout their life cycle and require hospitals to provide health services that are safe, high quality; anti-discrimination and effective ultimate the interests of the patient in accordance with standard service hospital (Act No. 44 of the year 2009 of the hospital).

Papua is one of the provinces in Indonesia with HIV spreading rate the second highest in Indonesia after East Java that is as much as 13,398 sufferers (Ministry of health of the Republic of Indonesia, 2017). HIV/AIDS is one disease that is classified into illness requiring palliative care because it is considered as a disease that cannot be cured up to this point (Ministry of Health No. 812/2007).

Palliative care carried out by hospitals or Clinics on the patient's end of life greatly influence on prolong life these patients and the hospitals or community center are required to have and prepare the concept of palliative care in instances of them. This is in line with the study of literature conducted by Erna Wirawan year 
2013 where it is said that palliative care was very instrumental in the achievement of a maximum quality of life in patients of cancer stage IV thus reducing pain or preparation against death $[13,14]$.

b. Referral system handling patient home conditions with the forced end of life care to affordable services to the location of the client.

One of the major parts in the organization of health services referral is system health. References to health submission are the responsibility of one Ministry of health. Notoadmojo extended IE as a system of organizing health services carry out reciprocal responsibility of a case of disease. System health services referral health facilities conducted from low to high or a simple to the plenary or otherwise with the purpose of providing health services to the community in holistic because of the many factors causes such as affordability and demography a region [15-17].

In depth interview with a participant noted that the hospital never gave descendent referral system to seek performed care palliative home care. This fact will greatly help the welfare of patients in reducing the suffering endured due to diseases palliative. In the context of the reference service of palliative patients are known to be forcibly returned home due to a difficult disease were condemned to be cured should be doing the reference of the Hospital where patients were being treated to a community health service center in where the client is domiciled in order to do it in the home care from a nearby institution. This is in accordance with the Ministry of Health Regulation Number 812 year 2007 about Palliative Care.

c. The readiness of public health care in palliative care will be the order of the family and the community.

In depth interview is with the community health center in mind that they did not prepare its staff members in handling patients with palliative conditions. Whereas in Eastern culture, communities have sentencing in Indonesia when it has suffered from the disease of end of life, they will immediately return his family to do home care as a form of service to the client. In the context of such where the community should get treatment which is holistic less cared for. In depth interview with the community health center in mind that they are less or not understanding in depth about the role of health workers of community health workers are not only the building but must be more maximum outside the building.

Regulations are concerning palliative care already in the pass that the existences of a palliative care home care. Palliative care home care maximum should be carried out by community health workers in the team have been trained or the families of the officers supervise clients over palliative care. Health workers especially in community health center sued for more proactive in preparing its staff members formed a team of palliative care at home or community $[18,19]$.

\section{d. Understanding doctors and nurses in the community} in providing palliative care at home.

A health worker is required to understand the scientific knowledge in the handling of their patients. Patient service especially for palliative cases should have been understood and even more should be developed in an area known to have a high percentage of sufferers of the palliative disease. In depth interview with participant in the know that understanding palliative or disease is understood only in the context of palliative in the previous College. Training and refresher activities for palliative care clinics or community should be more optimized. Based on the regulation of the Minister of health the year 2007 it is known that the goal of palliative care is how patients can be more prosperous in the face or preparing for his death. This research is simultaneous with study of Traister Erin and friends 2016 that training must be promoted to nurses for facilitate communication with families and patients during the end of life clients [20-22].

e. The accuracy of the information and data about the needs and support social, psychological and spiritual health problems in the handling of clients who experienced firsthand.

Palliative patients are patients who physically have in sentencing there is no hope of a cure except upon a miracle from God Almighty. In the context of the holistic care note that duty officers serve the patient in health is comprehensive i.e. bio, psycho, social, and spiritual. In depth interviews with patients who are end of life care in mind that they are in need of psychosocial and spiritual impetus due to severe anxiety that had befallen him. In theory it is known that psychological stress is going to suppress the resistance of the body affected clients to decrease body function in client which resulted in drastic to comprehensive weaknesses quickly. According to the Matzo and 2015 years Sherman stated that the needs of patients not only palliative treatment of physical symptoms but strong support to the needs of psychology, social, and Spiritual. With the strong support is expected to help clients more prosperous that can prolong support from their life.

\section{Summary}

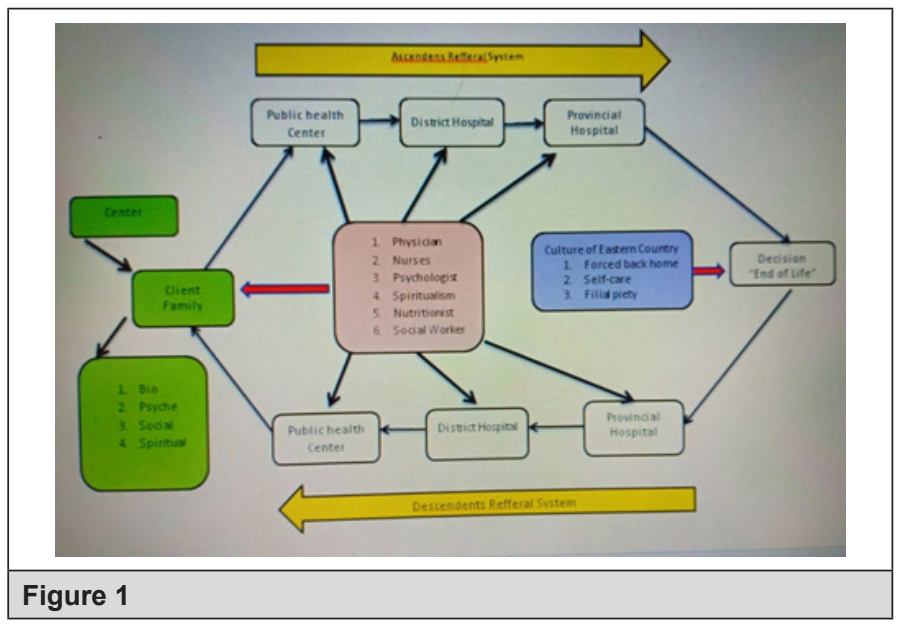


Based on the research was conducted, we found the model of referral system from the bottom of clinical area to the highest type of the hospital (Figure).

In the referral system model above explain that client and the family are the center of health care system of Palliative care. As regulation of the Indonesian government, all clients must be attended in the lower type of the hospital before coming to the type $\mathrm{A}$ of the hospital with referral system. In the lower type of the hospital until the higher type of the hospital, they must provide palliative team health care system to give care to the client with terminal diseases. The culture of eastern people is bringing home to their family when the doctor or nurses inform their family about the terminal diseases of their family. The government or the high type of the hospital must give descendent referral to the lower type hospital or public health center around client's home. So, the palliative team can give care to client all the time client's need.

\section{Acknowledgement}

We are grateful for funding from Ministry of Technology and Higher Education with number B/2708/E5.3/KL.03.01/2019, and Ministry of Health of Indonesian Republic with number UM.01. D1/4/6416/2019 to present my research in Transcultural Nursing Society Conference in Richmond Virginia October16-19, 2019. Our extended thanks are to Mayor of Papua Province and the participants in our research.

\section{Funding}

The author(s) received no financial support for the research, authorship, and/or publication of this article.

\section{Declaration of Conflicting Interests}

The authors declared no potential conflict of interest with respect to the research, authorship, and/or publication of this article.

\section{Data Availability}

No data were used to support this study

\section{References}

1. Mendri, Ni Ketut (2009) Hubungan Pemberian Informasi Tindakan Invasif Oleh Perawat Dengan Pemahaman Hak Pasien Rawat Inap Di IRNA I RSUP Sardjito Yogyakarta.
2. Rasjidi Imam (2010) Perawatan Paliatif Suportif \& Bebas Nyeri Pada Kanker, CV Sagung Seto, Jakarta.

3. Guwandi (2000) Bioethics \& Biolaw. Faultas Kedokteran Universitas Indonesia, Jakarta.

4. Achadiat Chritiono M (2007) Dinamika Etika \& Hukum Kedokteran dalam Tantangan Zaman ECG, Jakarta.

5. Azrul Azwar (1996) Pengantar Administrasi Kesehatan. Edisi Ketiga. Jakarta: Binarupa. Aksara.

6. Asshiddiqie Jimly (2005) Demokrasi Dan Hak Asasi Manusia Ketua Mahkamah Konstitusi Republik Indonesia dan Guru Besar Hukum Tata Negara Fakultas Hukum Universitas, Indonesia.

7. (2016) BNN Propinsi Papua.

8. Departmen Kesehatan (2009) Sistem Kesehatan. Indonesia.

9. Departmen Kesehatan (2007) Direktorat Jendral Bina pelayanan Medik Standar Minimal Pelayanan Kesehatan Gigi Puskesmas.

10. Hari Dj, Maulana (2007) Promosi Kesehatan, Jakarta: Buku Kedokteran EGC. Pp.12-13

11. Komalawati D, Veronica (1989) Hukum dan Etika dalam Praktek Dokter, Pustaka Harapan Jakarta

12. Kozier (2000) Fundamentals of Nursing: concept theory and practices. Philadelphia Addison Wesley.

13. LSD (2015) Kertas Sipembuat Halusinasi Jakarta.

14. Majalah NIAT Edisi II/2013 Penulis: Anwar Nuris

15. Meilani Niken dkk (2009) Kebidanan Komunitas. Yogyakarta: Fitramaya.

16. Y Absah (2011) Chapter II Pdf-USU Institutional Repository. Penerbit: Universitas Sumatra Utara1-10.

17. Perry, Potter (1997) Fundamental Keperawaran, Buku Ajar Konsep, Proses dan Praktik, (Alih Bahasa: Yasmin Asih, dkk) Ed. 4, EGC, Jakarta.

18. Sutarno (2012) Eutanasia Yang Tidak Disadari Di Rumah Sakit, disampaikan dalam Kongres Masyarakat Hukum Kesehatan Indonesia.

19. Syafrudin, Hamidah (2009) Kebidanan Komunitas. EGC Jakarta.

20. Tejawinata Sunaryadi (2008) Perawatan Paliatif adalah Hak Asasi Setiap Manusia, disampiakan pada seminar peringatan hari paliatif sedunia.

21. Traisler Erin, Kim L Larson, Dell Hagwood (2016) At the Grave We Make Our Song: A Palliative Care Study in Rural Guatemala. Journal of Transcultural Nursing 29(1): 38-45

22. WHO (2009) WHO Definition of Palliative care. 